\title{
Purification of carp (Cyprinus carpio) kidney cathepsin C
}

\section{(Pemurnian enzim cathepsin $\mathrm{C}$ dari ginjal ikan mas Cyprinus carpio)}

\author{
Pangkey H. dan Lantu S.
}

\begin{abstract}
Pemurnian enzim cathepsin $\mathrm{C}$ diperoleh melalui penggunaan colom kromatografi SSepharose FF, Sephacryl S-200 HR, Concanavalin A-Agarose, Affi-gel 501 dan DEAESephacel. Dari 160 g ginjal ikan mas diperoleh 0,33 mg enzim cathepsin C, dengan hasil pemurnian 150 kali. Berat molekul cathepsin C adalah $170 \mathrm{kDa}$ yang terdiri dari 5 subunit, dengan berat molekul berkisar antara 10 sampai $20 \mathrm{kDa}$. Cathepsin $\mathrm{C}$ adalah oligomerik protein dan aktif sebagai eksopeptidase ( $\mathrm{pH}$ 5) maupun endopeptidase ( $\mathrm{pH} 7$ ).
\end{abstract}

\section{INTRODUCTION}

Cathepsin C [EC 3.4.14.1] is a lysosomal cathepsin ${ }^{6,10}$ and involves in intracellular protein degradation. Because of its specificity (the ability toward dipeptidyl derivatives), cathepsin $\mathrm{C}$ has other common names. It is also familiar to be designated as aminopeptidase, dipeptidyl aminopeptidase I, or dipeptidyl peptidase $^{5,12}$. Lately, cathepsin C was defined as a lysosomal exopeptidase which is capable of removing dipeptides sequentially from the amino terminus of a peptide chain ${ }^{6}$. The function of cathepsin $\mathrm{C}$ besides the important role in intracellular protein degradation, it appears also to operate in cell growth and neurominidase activation. In addtion, cathepsin $\mathrm{C}$ is supposed to be involved in the function of the alimentary tract ${ }^{3,4,6}$. So far, this enzyme has been purified in bluefly, frog, gastropods, squid, chicken, mouse, rabbit, lamb, ox and human ${ }^{5}$. The purpose of the present study was to purify cathepsin C from kidney carp Cyprinus carpio.

\section{MATERIALS AND METHOD}

\section{Purification of cathepsin C}

The purification method of cathepsin $\mathrm{C}$ was done following the method as described by Minotani ${ }^{13}$ with a slight modification. About $160 \mathrm{~g}$ of frozen carp kidney thawed at $4^{\circ} \mathrm{C}$, minced, and homogenized with 5-fold of $50 \mathrm{mM}$ sodium acetate buffer, $\mathrm{pH}$ 5.5, containing $1.0 \mathrm{mM}$ DFP and $10 \mathrm{mM}$ EDTA. The homogenized solution was centrifuged at $9,000 \mathrm{x}$ g for $30 \mathrm{~min}$ to get a crude extract. The fraction precipitated with $20-70 \%$ saturation of ammonium sulfate was dissolved in a minimum volume in $50 \mathrm{mM}$ sodium acetate buffer, $\mathrm{pH} 4.0$ then dialyzed against the same buffer. After centrifugation at 12,000 x $\mathrm{g}$ for $30 \mathrm{~min}$, the supernatant was applied to an S-Sepharose Fast Flow column $(2.64 \times 45 \mathrm{~cm})$ equilibrated with the same buffer as in dialysis. The enzyme was eluted with a linear gradientof $\mathrm{NaCl}$ from 0 to $1.0 \mathrm{M}$ in the same buffer. The active fractions were pooled, concentrated by ultrafiltration (Amicon YM-10). The enzyme concentration was subjected to a Sephacryl S-200 column $(1.5 \times 100 \mathrm{~cm})$ equilibrated with $50 \mathrm{mM}$ 
sodium acetate buffer, $\mathrm{pH}$ 5.5, containing $0,2 \mathrm{M} \mathrm{NaCl}$ and $10 \mathrm{mM}$ EDTA and eluted with the same buffer. The active fraction was collected and dialyzed against $50 \mathrm{mM}$ potassium phospate buffer, $\mathrm{pH}$ 6.0, containing 0,15 $\mathrm{M} \mathrm{NaCl}$ and applied to a Concanavalin A-Agarose column $(1.0 \times 8.5 \quad \mathrm{~cm})$ equilibrated with the same buffer as in dialysis. It was washed with the same buffer followed by $0.1 \mathrm{M}$ methyl $\alpha$-Dmannopyranoside in the buffer. The active fractions were pooled and put on an Affi-Gel 501 column $(1.0 \times 5.0 \mathrm{~cm})$ equilibtared with $50 \mathrm{mM}$ sodium acetate buffer, pH 5.0, containing $0.15 \mathrm{M} \mathrm{NaCl}$ and eluted with the same buffer containing $10 \mathrm{mM}$ cysteine. The active fractions were pooled and put on a DEAE-Sephacel column $(0.5 \times 7.7 \mathrm{~cm})$ equilibrated with $50 \mathrm{mM}$ sodium phosphate buffer, $\mathrm{pH}$ 7.5. The column was washed with the same buffer, then eluted with $50 \mathrm{mM}$ sodium dihydrogen phosphate and followed by $0.3 \mathrm{M} \mathrm{NaCl}$ in $50 \mathrm{mM}$ sodium dihydrogen phosphate.

\section{RESULT AND DISCUSSION}

On the present study carp cathepsin $\mathrm{C}$ could hydrolyze H-Gly-Phe$\beta$ nap and Z-Phe-Arg-MCA as well. The latter was found to be the excellent substrate for cathepsin B, L and S which are the endopeptidase. This finding was proved that cathepsin $\mathrm{C}$ was an endopeptidase too. Previous study described that cathepsin $\mathrm{C}$ could not digest Z-Phe-Arg-MCA ${ }^{7}$, however, bovine spleen cathepsin $\mathrm{C}$ can degrade Z-Phe-Arg-MCA efficiently ${ }^{11}$. The purification step on column chromatographies could be seen in Fig. 1 - 5 and the enzyme was purified about 150 fold and produced $0.33 \mathrm{mg}$ cathepsin C. Cathepsin C was not sufficiently separated from cathepsin S on SSepharose column chromatography because the main peak of cathepsin $\mathrm{S}$ was eluted just before cathepsin C. It was effectively separated from cathepsin S on Sephacryl S-200 gel filtration because the molecular mass of cathepsin $\mathrm{C}$ was larger $(170 \mathrm{kDa})$ than cathepsin $\mathrm{S}^{14}$ (37 or $\left.40 \mathrm{kDa}\right)$. Cathepsin $\mathrm{C}$ was expected to contain carbohydrate. The enzyme was found to bind strongly to a Concanavalin A-agarose column. This property shares with cathepsin $\mathrm{H}$ (an exopeptidase) $)^{1,14}$ and cathepsin $\mathrm{L}$ (an endopeptidase) $)^{2,8-9}$. The affinity chromatography, Affi Gel 501, also was effective in the purification of this enzyme. Finally, on the DEAE-Sephacel column chromatography, it was found that this column was very effective in purification of this enzyme. The column has the capacity to separate cathepsin $\mathrm{C}$ from the other protein. The purified cathepsin $\mathrm{C}$ was examined through the analytical polyacrylamide gel electrophoresis using a 16-18\% gradient gel (Fig. 6). A single protein band was seen when a gel was stained for protein with silver stain and the protein band was reacted with anti-rat cathepsin $\mathrm{C}$ (Fig. 7).

\section{References:}

1. Aranishi F., K. Hara, and T. Ishihara, 1992. Purification and characterization of cathepsin $\mathrm{H}$ from hepatopancreas of carp Cyprinus carpio. Comp. Biochem. Phisiol., 102b, 499 505.

2. Aranishi F., K. Hara, K. Osatomi and T. Ishihara, 1997. Cathepsin B, $\mathrm{H}$ and $\mathrm{L}$ in peritoneal macrophages and hepatopancreas of carp Cyprinus carpio. Comp. 
Biochem. Phisiol., 117B, 605 611.

3. D’Agrosa R.M. and J.W. Callahan, 1988. In vitro activation of neuroamidase in the $\beta$ galactosidase-neuroamidaseprotective protein complex by cathepsin C. Biochem. Biophys. Res Commun., 157, 770 - 775.

4. Doughty M.J. and E.I. Gruenstein, 1987. Cell growth and substrate effects on characteristics of a lysosome enzyme (cathepsin $\mathrm{C}$ ) in duchene muscular dystrophy firoblasts. Biochem. Cell Biol., 65, $617-625$.

5. Hameed K.S. and N.F. Haard, 1985. Isolation and characterization of cathepsin C from Atlantic short finned squid (Illex illecebrosus). Comp. Biochem. Phisiol., 82B, $241-246$.

6. Ishidoh K., D. Muno, N. Sato, E. Kominami, 1991. Molecular cloning of cDNA for rat cathepsin $\mathrm{C}$ : cathepsin $\mathrm{C}$, a cysteine proteinase with an extremely long peptide. J. Biol. Chem., 266, 16312 - 16317.

7. Kuribayashi M., H. Yamada, T. Ohmori, M. Yanai and T. Imoto, 1993. Endopeptidase activity of cathepsin C, dipeptidyl aminopeptidase I, from bovine spleen. J. Biochem., 113. 441 449.

8. Mason R.W., M.A.J. Taylor and D.J. Etherington, $1984 . \quad$ The purification and properties of cathepsin L from rabbit liver. Biochem. J., 217, 209 - 217.

9. Mason R.W., G.D.J. Green and A.J. Barret, 1985. Human liver cathepsin L. Biochem. J., 226, $233-241$.
10. Mcdonald J.K., T.J. Reilly, B.B. Zeitman and S. Ellis, 1968. Dipeptidyl arylamidase II of the pituitary. J. Biol. Chem., 243, 2028 - 2037.

11. Mcdonald J.K., B.B. Zeitman, T.J. Reilly and S. Ellis, $1969 . \quad \mathrm{New}$ observation on the substrate specificity of cathepsin C (Dipeptidyl Aminopeptidase I). J. Biol. Chem., 244, 2693 2709.

12. Metrione R.M. and N.L.MacGeorge, 1975. The mechanism of action of dipeptidyl aminopeptidase. Inhibition by amino acid derivatives and amines; Activation by aromatic compounds. Biochemistry, 14, 5249 - 5252.

13. Minotani T., 1996. Study of cathepsin C on carp kidney. Master thesis, University Nagasaki, Nagasaki. 47p.

14. Pangkey H., H. Kenji, K.Tachibana, M.J. Chao, K. Osatomi, T. Ishihara, 2000. Purification and characterization of cathepsin S from hepatopancreas of carp Cyprinus carpio. Fisheries Science, Vol. 66, 1130 - 1137.

15. Schwartz W.N. and A.J. Barrett, 1980. Human cathepsin $H$. Biochem. J., 191, 487 - 497. 


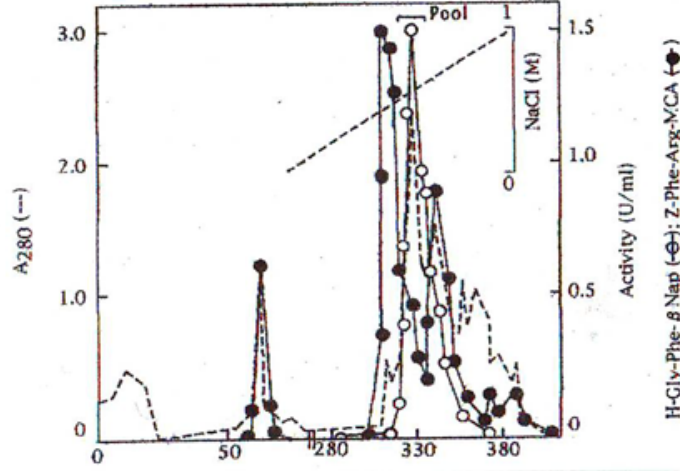

Fig.1 Chromatography of the ammonium sulfate fraction on S-Sepharose column Chromatography

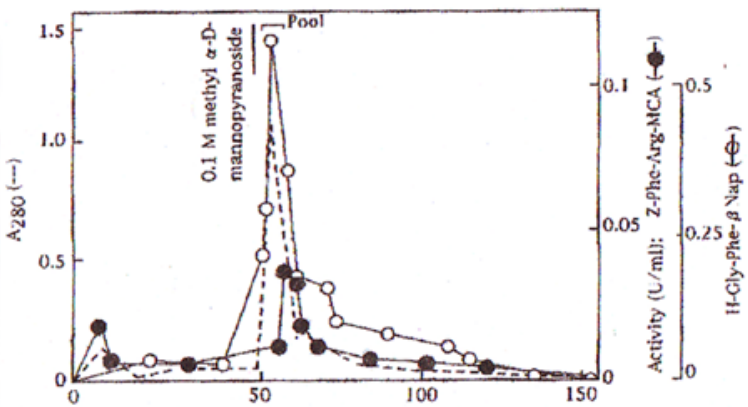

Fig.3 Affinity Chromatography of Sepharyl S-200 HR fraction on a Concanavalin A-agarose column

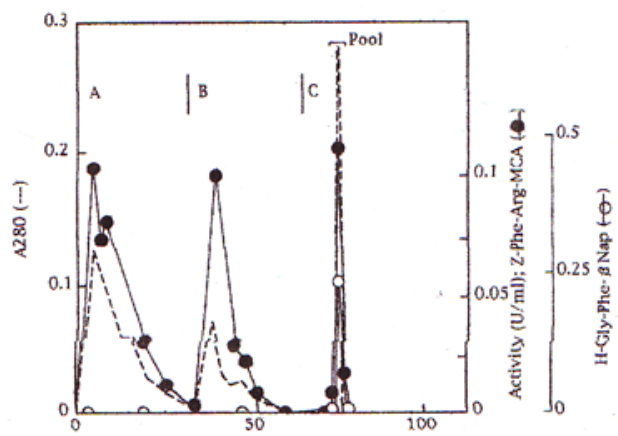

Fig.5 Affinity Chromatography of Affy-Gel 501 fraction on DEAE-Sephacel column

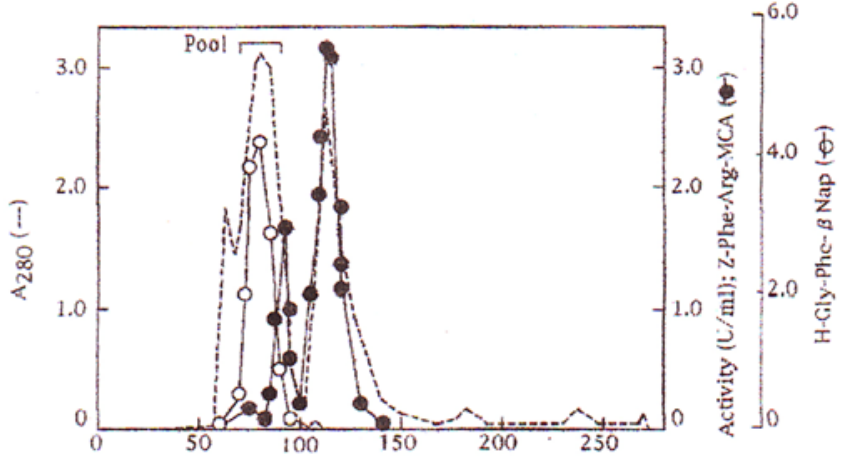

Fig.2 Chromatography of S-Sepharose fraction on a Sepharyl S-200 HR column

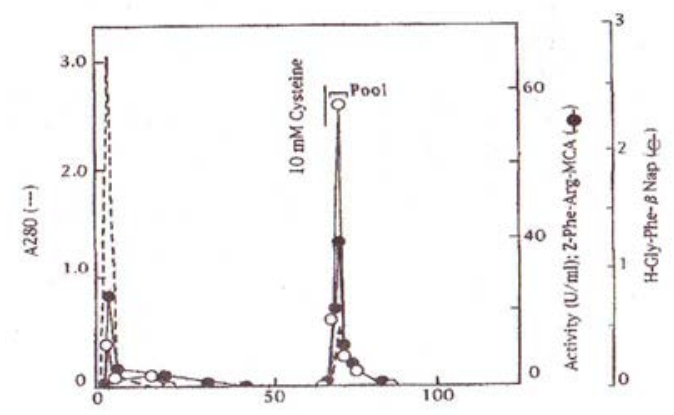

Fig.4 Affinity Chromatography of Con A-agarose fraction on Affi-Gel 501 column 


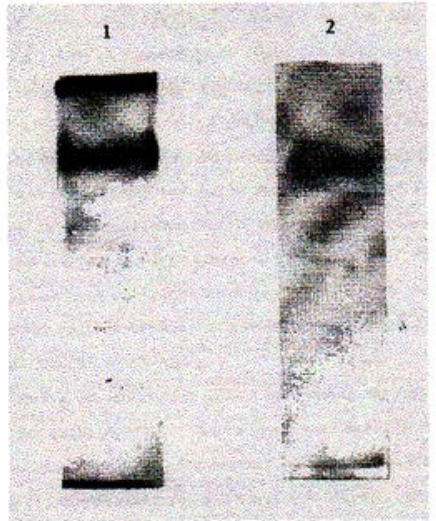

Fig. 6 Analytical polyacrylamide gel electrophoresis and immunoblotting of the purified carp cathepsin C

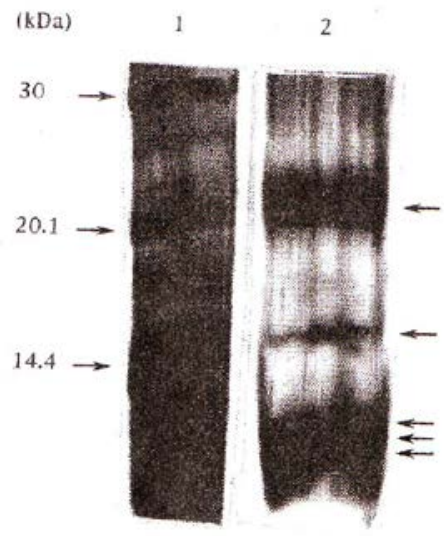

Fig. 7 SDS-PAGE of carp cathepsin C on 16-18 gradient gel 